\title{
A Study of Chipped Stone Artifacts from the Redwine Site (41SM193), Smith County, Texas
}

Harry J. Shafer

Follow this and additional works at: https://scholarworks.sfasu.edu/ita

Part of the American Material Culture Commons, Archaeological Anthropology Commons, Environmental Studies Commons, Other American Studies Commons, Other Arts and Humanities Commons, Other History of Art, Architecture, and Archaeology Commons, and the United States History Commons

Tell us how this article helped you.

This Article is brought to you for free and open access by the Center for Regional Heritage Research at SFA ScholarWorks. It has been accepted for inclusion in Index of Texas Archaeology: Open Access Gray Literature from the Lone Star State by an authorized editor of SFA ScholarWorks. For more information, please contact cdsscholarworks@sfasu.edu. 


\section{A Study of Chipped Stone Artifacts from the Redwine Site (41SM193), Smith}

County, Texas

\section{Creative Commons License}

\section{(c) (1) (8)}

This work is licensed under a Creative Commons Attribution-NonCommercial 4.0 International License 


\title{
A STUDY OF CHIPPED STONE ARTIFACTS FROM THE REDWINE SITE (41SM193), SMITH COUNTY, TEXAS
}

\author{
Harry J. Shafer
}

\section{INTRODUCTION}

This article presents a detailed analysis of chipped stone artifacts from the Redwine Site (41SM193), a Middle Caddo mound and village site located on the headwaters of Auburn Creek, a tributary of the Sabine River. The collection includes chipped stone recovered from the surface, test excavations, and arrow points associated with two adult burials. The site was investigated by avocational archeologist Sam Whiteside in the 1960s and more recently by Mark Walters and Patti Haskins under the direction of John Keller of Southern Archaeological Consultants (Walters and Haskins 1998). The investigations and material culture have been briefly described (Walters and Haskins 1998). This study is designed to take a closer look at the lithics with an emphasis on technological, material, contextual, and typological analyses of the lithic artifacts, and to compare the findings to the lithics at the nearby and possibly contemporaneous Leaning Rock site (4ISM325).

Archaeologists generally have not focused on Caddo lithic technology, and this class of material culture remains only cursorily studied. Rather, ceramics have received the vast amount of attention with little emphasis on other types of material culture. One reason for a lack of attention to lithics may be that East Texas generally lacks the resources from which well-crafted artifacts could have been made (Banks 1990). Small chert cobbles or pebbles, and pebbles of orthoquartzite and silicified wood constitute the major sources for chipped stone. Lacking are outcrops of excellent chert (such as the Edwards Plateau) or novaculite (eastern Oklahoma and southwestern Arkansas). Artifacts of from these two sources are introduced into East Texas in finished form. Edwards chert and novaculite debitage found in East Texas sites is likely from recycling broken finished artifacts. When lithics are reported, they are generally relegated to brief descriptive treatments with an emphasis on artifact classification and raw material distribution. Detailed technological treatments are rare (for exceptions, see Brewington et al. 1995; Girard 1995; Shafer 1973).

lt is preferable in archaeological studies to integrate all classes of material culture in analysis and interpretation to see what sets of material co-occur both functionally, technologically, stylistically, and symbolically (Shafer 2007a). Rarely is this extended effort even attempted in archaeological studies in Texas, but until all surviving aspects of material culture are integrated and interpreted as a cultural whole and within the known context of Caddo culture and life way, only fragments of past cultures will be stressed with the risk of gross misinterpretation. While it is acknowledged that this study treats only a fragment of the material culture from the Redwine site, I will attempt to integrate the findings in such a way as to relate it to extant information from the site available to me from other sources. Another objective of this study is to examine the lithics from the Redwine site and compare them with the sample from the nearby Leaning Rock site 
(Shafer 2007b). Both collections are assumed to be approximately the same age and may be from the same extended Middle Caddo community (Walters and Haskins 1998). I will specifically emphasize the technological styles (Lechtman 1977) of the formal tools and the implications of the debitage with regards to technology and raw material.

\section{REDWINE SITE (41SM193)}

The Redwine site is a small Middle Caddo mound and village. The site probably consisted of several structures forming a plaza fronting the mound. The site has been designated as a State Archeological Landmark by the Texas Historical Commission (Walters and Haskins 1998). As noted above, the site was investigated by avocational archaeologist Sam Whiteside in the 1960s. More recently Mark Walters and Patti Haskins conducted test excavations in 1995 (Walters and Haskins 1998). Both Whiteside's and Walters and Haskins' excavations are briefly described below.

\section{Whiteside Excavations}

Excavations by Sam Whiteside, an avocational archaeologist, have been described by Timothy K. Perttula (in Walters and Haskins 1998:22-35). Whiteside used a small tractor and slip to remove the mound and used a shovel and trowel to explore for features beneath the structure. Whiteside documented a post hole pattern of a circular structure ca. $5.5 \mathrm{~m}$ in diameter with an extended entryway oriented to the southeast. Whiteside left an unexcavated block in the center of the structure and did not record the interior hearth feature.

In addition to the mound excavation, Whiteside excavated four adult burials. Perttula was unable to locate the burials in relation to the mound or midden area, and speculated that all were extended supine, the pattern that would be expected for Middle Caddo graves. Skeletal material was very poorly preserved, and none was recovered. Grave contents, however, give some hint with regards to gender. Burial 1 had 11 ceramic vessels, two ceramic pipes, and 18 arrow points. Burial 2 had four ceramic vessels. Burial 3 had nine ceramic vessels, one ceramic pipe, and six arrow points. Burial 4 had four ceramic vessels. Burials 1 and 3 were most likely males based on the associations of pipes and arrow point; Burials 2 and 4 may have been females although the absence of skeletal material and gender-specific artifacts makes such a judgment speculative.

\section{Investigations}

Walters and Haskins excavated a series of shovel tests at the Redwine site in 1995, along with a controlled surface collection. The surface collection identified a sherd concentration within a midden area identified by slightly darker soils. Based on the shovel tests and surface collection, a block excavation was carried out in the midden area. Nineteen 1 x $1 \mathrm{~m}$ excavation units removed $8.8 \mathrm{~m}^{3}$ of fill. Over 5900 artifacts were recovered from the block excavation and several features were identified, including post holes and a fire hearth (Walters and Haskins 1998). The rich artifact sample included 
ceramics, lithics, faunal remains, and botanical remains. A single radiocarbon date of $570 \pm 50$ B.P. (calibrated at two sigma to AD 1304-1434) was obtained from charred nutshells from Feature 3, the hearth.

\section{Ceramic Assemblage}

The ceramic assemblage from the site includes both whole vessels and a large sherd collection. The vessel collection was examined by Timothy K. Perttula (in Walters and Haskins 1998:25-38), and the following summary is taken from his report. According to Perttula, the ceramics are classified as Middle Caddo in age and compare most closely as an assemblage to the ceramics from the Washington Square Mound site (4INA49, Corbin and Hart 1998). Specifically, Perttula noted the presence of at least four vessels that he typed as Nacogdoches Engraved, a type first defined at the Washington Square Mound site. Also, there was one vessel each of Pennington Punctated Incised and Crockett Curvilinear Incised in the assemblage. These types were first defined at the George C. Davis site (41CE19) by Krieger (Newell and Krieger 1949:81-129). The possible significance of these named types in the Redwine site assemblage is discussed in more detail below.

\section{Faunal Remains}

Faunal remains from the site consisted of 1,353 elements and were examined by David Jurney (in Walters and Haskins 1998:15). Most were small fragments of unidentified bones from large, medium, and small animals. Jurney was able to identify 10 species of taxa; these included mussel, fish, turtle, wild turkey, duck, rabbit, raccoon, canid(?), and deer. No bone artifacts were identified in the faunal assemblage.

\section{Botanical Remains}

A small sample of botanical remains were recovered from flotation samples analyzed by S. Eileen Goldborer (in Walters and Haskins 1998:15-22). While small, the findings are nevertheless significant. Wood charcoal dominated the sample, but charred hickory, sumac, wild grape seeds, and maize were recovered.

\section{CHIPPED STONE ASSEMBLAGE}

A total of 158 chipped stone are in the collection. Of these, 39 are projectile points, three are other tools, and 116 are classed as debitage. The lithics examined in this collection came from two sources: Whiteside's excavations, which yielded the mortuary arrow points, and the 1995 investigations, which included surface finds and excavated materials from the test units. 


\section{Projectile Points}

A total of 39 projectile points are in the collections, including three dart points and 36 arrow points.

\section{Dart Points}

Two dart points and a dart point fragment are in the collection, and the styles are not considered associated with the Caddo artifact assemblage. These points are briefly described below.

\section{Big Sandy $(n=1)$}

This point (Figure 1A) has a straight base, side notches characteristic of the type, and short triangular blade. Two attributes, the linear profile and the base, which is steeply chipped bifacially, suggest it was made from the snapped blade of a larger point. The linear profile shows an abrupt termination at the base rather than a tapered termination as would otherwise be expected. The material is a mottled yellowish-pink chert, non-local in origin. The point is classed as a Big Sandy rather than morphologically and perhaps chronologically similar point types Keithville (Turner and Hester 1999:134-135) and Palmer (Turner and Hester 1999:166) because Big Sandy has precedence in the archaeological literature and Keithville and Palmer points may be simply stylistic or technological variances of Big Sandy or San Patrice. Big Sandy is a Late Paleoindian style in the Southeastern United State.

Lot \#51. Length: $34 \mathrm{~mm}$; Width at base: $23 \mathrm{~mm}$; Thickness: $6 \mathrm{~mm}$.

\section{Expanding Stem Point $(n=1)$}

Made on white, non-local chert, this small dart point (Figure 1B) has an expanding stem with a slightly concave base. The blade has been extensively reworked almost to a nubbin. Technologically this is a dart point, and stylistically it fits closest to the defined type Edgewood (Turner and Hester 1999:111) although I hesitate to type the point.

Lot \#58. Length: $22 \mathrm{~mm}$; Width: $14 \mathrm{~mm}$; Thickness: $6 \mathrm{~mm}$.

\section{Dart Point Distal Fragment $(\mathrm{n}=1)$}

This distal tip of a dart point (Figure 1C) from Lot \#16, possibly a Gary or Yarbrough, is made of heat-treated orthoquartzite, a common material for Late Archaic and Early and Middle Woodland dart points in East Texas (Shafer and Green 2007). 

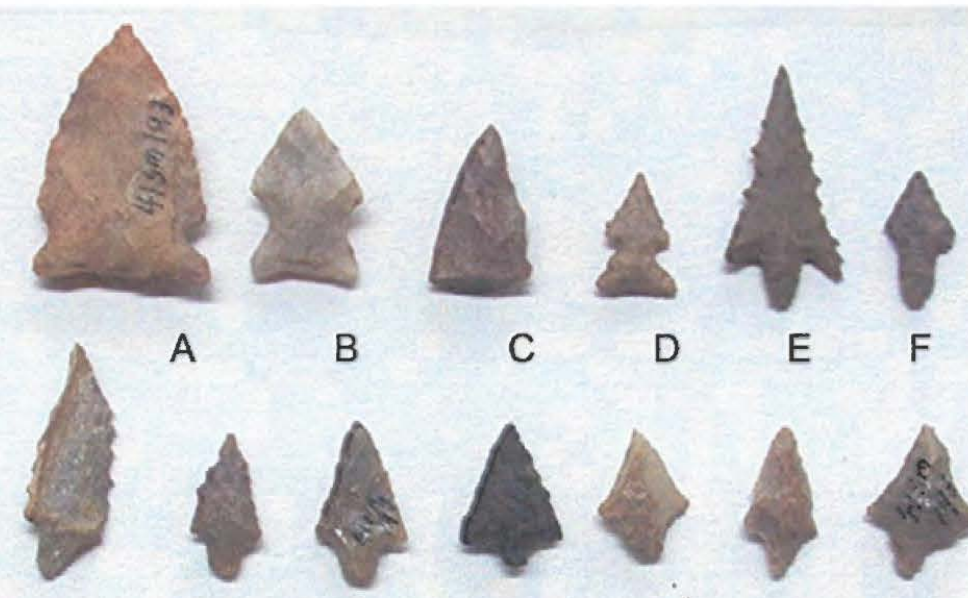

A

B

C

D

E

$\mathrm{F}$
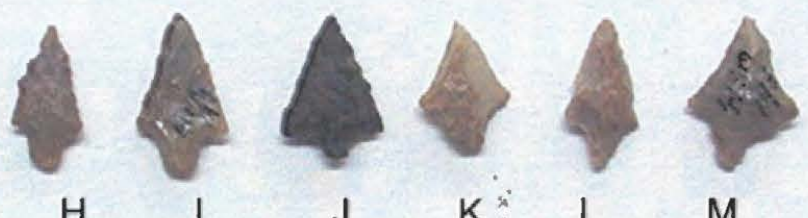

G

$\mathrm{H}$

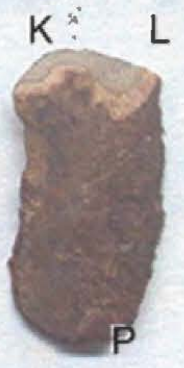

M

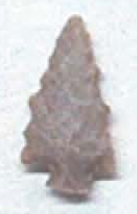

N

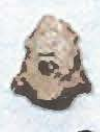

0

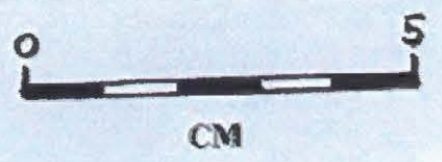

Figure 1. Lithic Artifacts. A-C, dart point; D-O, arrow points; $\mathrm{P}$, end scraper; Q, perforator. A, Big Sandy, B, Corner-notched, C, dart point tip; D, Scallorn/Morris, E, F, Perdiz, G-M, Perdiz-Bassett, N, untyped, O, fragment.

\section{Arrow Points}

Of the 36 arrow points in the sample, 12 were recovered from either the surface or from the 1995 excavations. These points are described separately from those recovered from mortuary context $(n=24)$.

\section{Scallorn/Morris $(n=1)$}

This extensively reworked arrow point (Figure 1D) is corner-notched with a slightly concave base and short triangular blade. It is bifacially worked. The material is a 
gray-tan non-local chert. This point, if found in Central Texas, would be classified as a Scallorn; it can also be classified as a Morris point (cf. Perttula 1997:Figure 1).

Length: $16 \mathrm{~mm}$; Width at base: $11 \mathrm{~mm}$; Thickness: $3 \mathrm{~mm}$.

$\operatorname{Perdiz}(\mathrm{n}=2)$

One specimen from Lot \#12 (Figure 1E) has a contracting stem, a barbed and serrated blade, and is made of a non-local olive chert comparable to olive Edwards chert the author has seen from Bosque and Coryell counties in Texas. This particular style of Perdiz is common in the prairies of Central Texas (Shafer 2007a; Gadus et al. 2002: Figure 91) associated with Caddo ceramics. It is very similar to points recovered from Feature 118 at the George C. Davis site as well (Shafer 1973: Figure 17R1-T1). The expert craftsmanship of this bifacially-worked specimen suggests the point may have been displaced by cultivation or bioturbation from a burial. Length: $31 \mathrm{~mm}$; width across barbs: $11 \mathrm{~mm}$; Thickness: $3 \mathrm{~mm}$.

The second Perdiz point (Figure 1F) (Lot \#36) also has the characteristic contracting stem, extensively reworked blade, missing barbs, and bifacial chipping. It too is olive brown chert but is a slightly different hue from the specimen from Lot \#12. Length: $18 \mathrm{~mm}$; Width: $9 \mathrm{~mm}$; Thickness: $3 \mathrm{~mm}$.

\section{"Perdiz-Bassett" ( $n=7)$}

As a group these points have short contracting stems, rounded or pointed bases and short triangular blades (Table 1), and have stem attributes of both Perdiz and Bassett, hence the tag "Perdiz-Bassett." All are poorly worked compared to the Perdiz illustrated in Figure 1E. Specimen G (Lot \# 79) is unifacial, and is of gray mottled fossiliferous chert that visually compares to Pisgah Ridge chert described by Banks (1990) and McGregor (1993), although direct comparisons are not possible. The color is lighter than that described for Pisgah Ridge, however, but this may be due to weathering.

Table 1. Perdiz-Bassett measurements in millimeters.

$\begin{array}{rrrrl}\text { Lot \# } & \text { Length } & \text { Width } & \text { Thickness } & \text { Figure } \\ 79 & 30 & 11 & 3 & 1 \mathrm{G} \\ 66 & 18 & 9 & 4 & 1 \mathrm{H} \\ 51 & 20.5 & 12 & 3.5 & 1 \mathrm{I} \\ 23 & 19 & 13 & 5 & 1 \mathrm{~J} \\ 26 & 16 & 13.5 & 4 & 1 \mathrm{~K} \\ 0 & 19 & 10 & 4 & 1 \mathrm{~L} \\ 51 & 19 & 14.5 & 6 & 1 \mathrm{M}\end{array}$

These are distinctive arrow points that probably deserve their own name classification since they occur throughout East Texas in Middle Caddo components, such as Oak Hill (4IRK214, Rogers and Perttula 2004: Figure 61), and Late Caddo-Historic 
Caddo components such as the Deshazo site (41NA27, Girard 1995). Girard's (1995:Figure 24) Contracting Stem Group II arrow points conform well to those described above. The Group 1 arrow points from Oak Hill, with the exception of Lots 1879 and 353 (Rogers and Perttula 2004: Figure 61), also compare well to those recovered from Redwine. "Perdiz-Bassett" are usually not associated with burials although the three specimens from Burial 3 at the Redwine site (see below) and Burial 1 at Oak Hill (Rogers and Perttula 2004:Figure 60a-f, h, j) are possible exceptions to this pattern.

Mortuary arrow points are usually very well made with much more skill than those found in midden deposits. The caveat is, of course, that the midden specimens may be discarded nubbins of points that were larger and better crafted, but I do not think this is the case. Midden arrow points are often made on small flakes, are often largely unifacially chipped, and do not appear to have been reduced through retouch.

\section{Arrow Point Fragments ( $=2)$}

One of these specimens (Lot \#51; Figure 1N) has a shouldered blade that is slightly serrated. The stem is broken. The workmanship is relatively crude compared to the mortuary specimens and the Perdiz (Lot \#12) described above, and only slightly better than those in the Perdiz-Bassett group. Length: $23 \mathrm{~mm}$; Width: $12 \mathrm{~mm}$; Thickness: $4 \mathrm{~mm}$.

The arrow point fragment (Figure 10) from Lot \#18 has a broken stem and tip.

\section{Mortuary Arrow points}

The mortuary arrow points from the Redwine site are described by burial and cluster. Clusters of arrow points undoubtedly represent bundles or quivers of arrows that were placed in the graves. Typological analysis will compliment the technological study, and the intent here is to show that while generic types do occur and have chronological significance, variability in form, technology, and material provide a challenge in liberally applying a generic typology.

\section{Burial 1, Cluster $1(n=7)$}

Point \#1 (Figure 2A ). Type: Perdiz variant. Made on a dark brown chert with tiny white and black specks, this point has a short contacting stem, barbed shoulders, and straight blade edges. It is made on a bifacial perform (Table 2). 


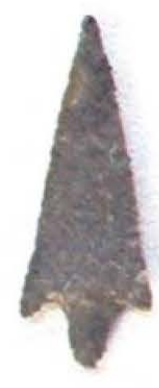

A

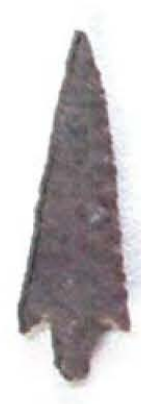

B

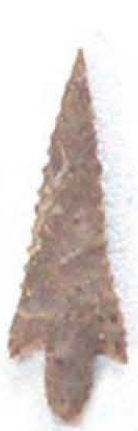

C

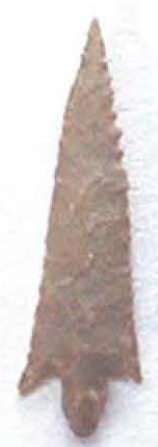

D

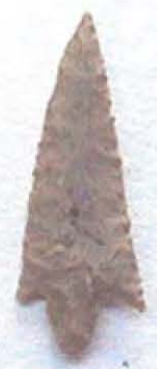

E

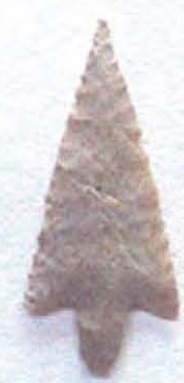

$\mathbf{F}$

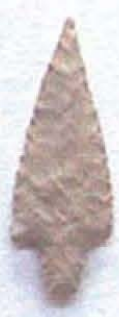

G

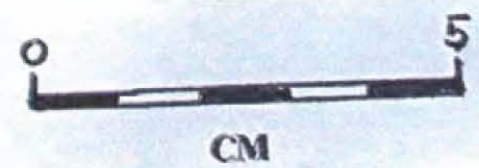

Figure 2. Burial 1, Cluster 1 arrow points. A, B,E-G, Perdiz variant; C, D, PerdizBonham.

Table 2. Measurements for Burial 1 Cluster 1 arrow points in mm.

Point \#
1
2
3
4
5
6
7

Length
41
41
41
50
40
41
34

Width

$\begin{array}{rl}\text { Thickness } & \text { Figure } \\ 4 & 2 \mathrm{~A} \\ 3 & 2 \mathrm{~B} \\ 3 & 2 \mathrm{C} \\ 4 & 2 \mathrm{D} \\ 3 & 2 \mathrm{E} \\ 4 & 2 \mathrm{~F} \\ 4 & 2 \mathrm{G}\end{array}$


Point \#2 (Figure 2B ) Type: Perdiz variant. This specimen also has a short contracting stem, straight blade edges, and was made on a bifacial perform. The chert is identical to that of Point \#1 and it is very likely they were made by the same knapper and of material from the same core.

Point \#3 (Figure 2C). Type: Perdiz-Bonham. This point is made of mottled tan chert with brown specks. It has a bulbar stem, a long, slightly serrated blade, and is manufactured on a flake perform.

Point \#4 (Figure 2D). Type: Perdiz-Bonham. This point has a bulbar stem with a pointed base. Barbs are long, and the blade is slightly re-curved with fine serrations near the type. It was made on a bifacial perform. Stylistically it is similar to Point \#3 but pressure flaking patterns suggest a different knapper.

Point \#5 (Figure 2E ). Type: Perdiz. Manufactured on tan chert, this point has a short contracting stem, a slightly asymmetrical blade with one straight and one slightly concave blade edge, and short barbs. The point was made on a biface perform and the pressure flaking patterns are similar to those displayed on points \#1 and \#2.

Point \#6 (Figure 2F ). Type: Perdiz. This contracting stem point has a barbed blade and is wider that the other points in the cluster (see Table 2). The material is tan chert with brown specks, similar to the material in Point \#3. It is finely pressure flaked but the blade is not serrated in contrast to Point \#3.

Point \#7 (Figure 2G). Type: Perdiz. The stem is contracting with a rounded base. The blade has small barbs with weakly convex blade edges. The pressure flaking pattern differs from all other points in the cluster.

Comments: I have classified two of the specimens as "Perdiz-Bonham" simply to differentiate the minor stem style. The difference is that Perdiz-Bonham stems are parallel from the base to about midway up the stems, at which point they taper to a rounded base. The stems on those that I classify as Perdiz are tapered the entire length of the stem. Now whether this made a "hill-a-bean" difference in the minds of the Caddo flint knappers I have no earthly idea, but this subtle difference in style may have differentiated one knapper from another.

Stylistically Points \#1-\#6 compare well to specimens Q1-T1 from Feature 118 at the George C. Davis site (Shafer 1973:Figure 17Q1-T1). Feature 118 yielded a single uncalibrated radiocarbon date of $770 \pm 80$ BP (AD 1100-1260) (Story 1997:61).

Differences in raw material, style, and pressure flaking patterns suggest to this analyst that perhaps as many as four separate flint knappers were responsible for this cluster. While all of the points are typologically similar, there are minor differences in style and technique to differentiate artisans. Each flint knapper, like any artist, has his own style of doing things even though they may work within a very tightly defined 
technological style (Lechtman 1978). The typological consistency of the cluster illustrates the technological style while the variability within defines the individuality of the artisan.

\section{Burial 1, Cluster $2(n=11)$}

This is a very stylistically similar cluster composed of mostly long and narrow points (Table 3) made of tan speckled chert. The material is identical to Point \#3 in Cluster 1, and its source is unknown. The cluster will be described as a group rather than individually because there is little doubt that they were made by the same flint knapper. Points 1-8 (illustrated in Figure 3A-H) have slightly contracting stems with indented bases. Shoulders are square and five (\#1-\#5) have long narrow blades while three (\#6$\# 8$ ) have shorter blades. All of the blades are slightly serrated. Point \#9 has a bulbar stem and Point \#10 has a contracting stem similar to Point \#7 in Cluster 1. The stem is missing on Point \#11.

Table 3. Measurements for Burial 1, Cluster 2 arrow points in mm.

$\begin{array}{rrrrl}\begin{array}{lrlr}\text { Cluster } 2 \\ \text { Point \# }\end{array} & \text { Length } & \text { Width } & \text { Thickness } & \text { Figure } \\ 1 & 38 & 10 & 3 & 3 \mathrm{~A} \\ 2 & 34 & 9 & 3 & 3 \mathrm{~B} \\ 3 & 29 & 9 & 3 & 3 \mathrm{C} \\ 4 & 28 & 8 & 3 & 3 \mathrm{D} \\ 5 & 27 & 9 & 3 & 3 \mathrm{E} \\ 6 & 20 & 9 & 3 & 3 \mathrm{~F} \\ 7 & 19 & 9 & 2.5 & 3 \mathrm{G} \\ 8 & 26.5 & 9.5 & 3.5 & 3 \mathrm{H} \\ 9 & 22 & 10 & 3 & 31 \\ 10 & 23 & 7 & 3 & 3 \mathrm{~J} \\ 11 & 23.5 & 8 & 3 & 3 \mathrm{~K}\end{array}$

Typing such a cluster is futile; the typological conundrum is exemplified by the fact that a single knapper is responsible for the lot. That being said, Point \#10 (Figure 3J) could be classified as Perdiz, while Point \#9 (Figure 31) could be classed as a BonhamAlba. The remaining points are similar to Cuney (Suhm and Jelks 1962:271-272), but differ in that Cuney points have straight or expanding stems while these are all contracting. A more accurate comparison can be seen with certain points from mortuary contexts at the George C. Davis site, specifically specimens F and G from Fea. 161 (Shafer 1973: Figure 16). There are other arrow points from the Davis site with straight stems and indented bases, for example from Fea. 119, 134, and 155 (Shafer 1973: Figure 15T-U, W, X, B1-C1, G1, I1-K1), but as a group these listed have proportionally wider blades than are displayed by the Cluster 2 points from Redwine. 

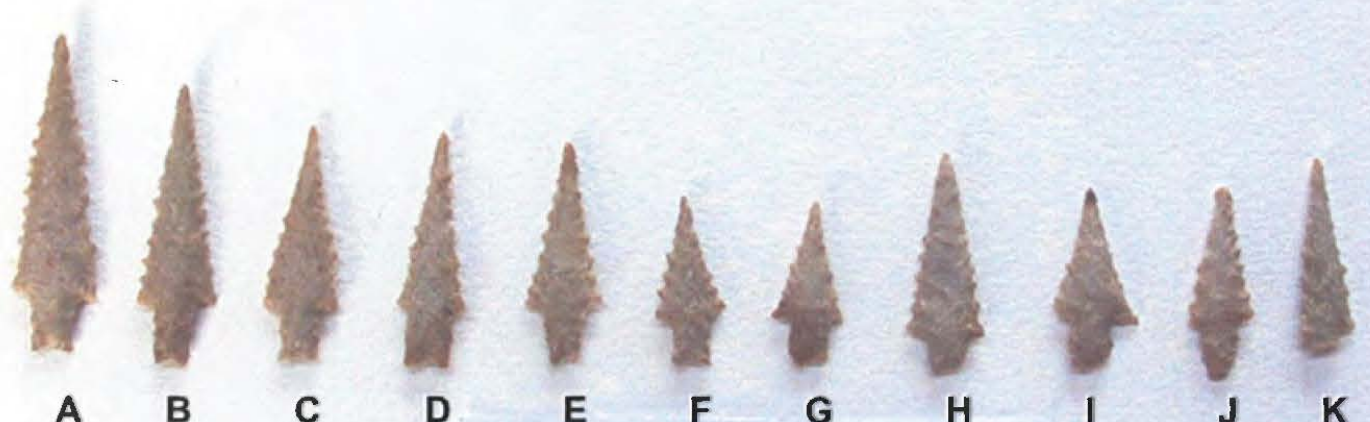

A B

D

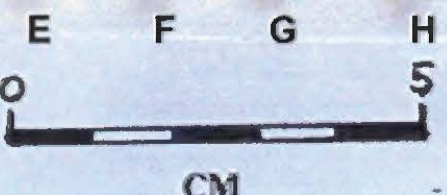

1

K

\section{CM}

Figure 3. Burial 1 Cluster 2 arrow points. This lot was made by the same knapper. The variability creates typological problems as A-F, H, K is untyped, and specimen I compares to Bonham-Alba while $\mathrm{J}$ is Perdiz-like.

The variability within the cluster can probably be explained by the difficulty in following a precise mental template while pressure flaking small chert artifacts. Therefore, it is perhaps not fruitful to engage in such typological discussion when the important attributes on these points are the overall technological style of manufacture, serrated blades, mostly indented bases, and identical raw material. Together these spell one flint knapper probably making a quiver of arrows, perhaps for the sole purpose for use as funerary items.

\section{Burial 3, Cluster $1(n=3)$}

These three points (Table 4) are all morphologically dissimilar and appear to have been made from scraps of chert. Point \#1 (Figure 4A) has an asymmetrical pointed stem, weak shoulders, and a triangular blade. Point \#2 (Figure 4B) has a slightly asymmetrical stem with a round base, prominent shoulders, and triangular blade that is very faintly convex. The stem on Point \#3 (Figure 4C) is short and square; the shouldered blade is 


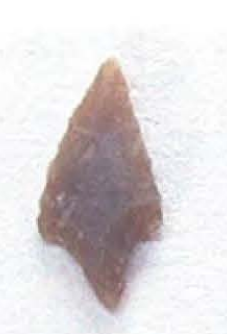

A

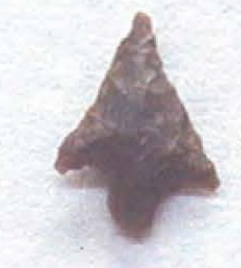

B

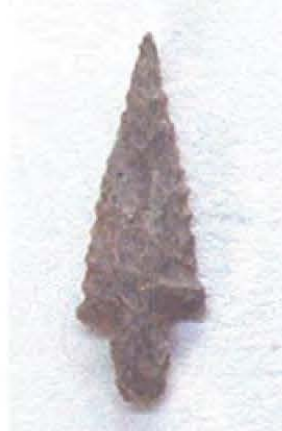

D

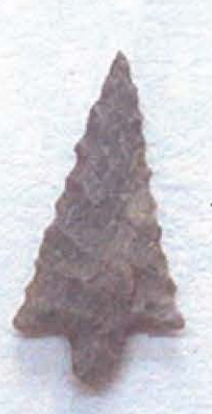

E
C
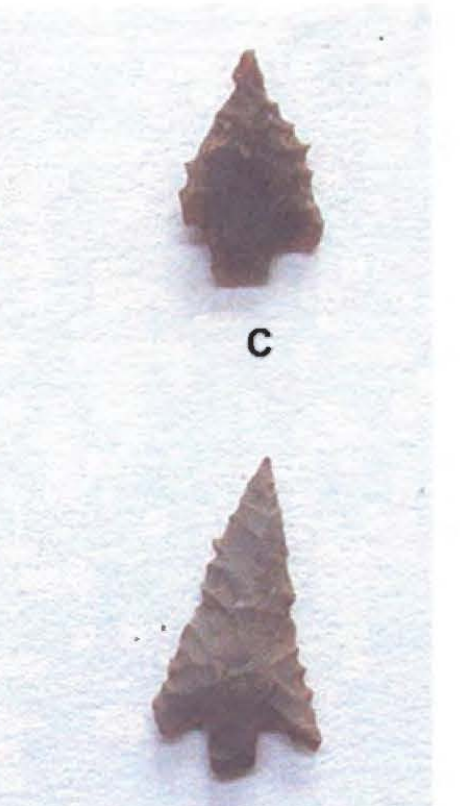

$\mathbf{F}$

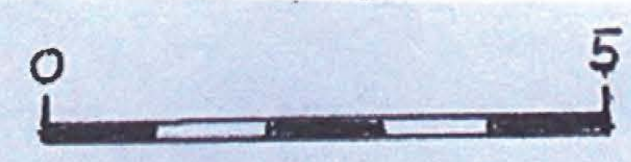

CM

Figure 4. Burial 3, Clusters 1 and 2 arrow points. A-C, untyped from Burial 3, Cluster 1; D-F, Bonham-Alba from Burial 3, Cluster 2.

asymmetrical and the blade is serrated. All are made on flakes of gray-tan chert. The cherts are all slightly different and doubtfully come from the same core.

Comment: This cluster of points more closely fit the variations and poor craftsmanship found in points recovered from midden and village contexts rather than the kinds of points often recovered from burials. They are so morphologically dissimilar that I would not venture to classify them according to type although Points \#1 and \#2 would probably be called Perdiz by most researchers.

Table 4. Measurements for Burial 3, Cluster 1 arrow points in mm.

$\begin{array}{rrrrl}\text { Point \# } & \text { Length } & \text { Width } & \text { Thickness } & \text { Figure } \\ 1 & 22.5 & 22 & 3 & 4 \mathrm{~A} \\ 2 & 19 & 15 & 4 & 4 \mathrm{~B} \\ 3 & 20 & 14 & 4 & 4 \mathrm{C}\end{array}$




\section{Burial 3, Cluster $2(n=3)$}

In contrast to Cluster 1 from Burial 3, these are all very well crafted points (Table 5) that fall closer to Bonham-Alba than any other established type. All are of a slightly different form, but that may be due to the expected variability in an effort to follow a mental template. Points \#1 and \#2 are of the same gray-tan chert. Point \#1 has a bulbar stem, with a shouldered, slightly serrated blade (Figure 4D). Point \#2 (Figure 4E) has a short, contacting stem and rounded base with a wider, slightly serrated blade. The third (Figure 4F) is of heat-treated tan chert with a red bulbar stem, barbed shoulders, and slightly serrated blade. All were probably made by the same knapper since: (a) Point \#1 and Point $\# 2$ are of the same material and probably came from the same core, and (b) the pressure flaking on the blades of Points \#2 and \#3 are virtually identical.

Table 5. Measurements for Burial 3, Cluster 2 arrow points in millimeters.

$\begin{array}{rrrrl}\text { Point \# } & \text { Length } & \text { Width } & \text { Thickness } & \text { Figure } \\ 1 & 32 & 11 & 3.5 & 4 \mathrm{D} \\ 2 & 29 & 15 & 4 & 4 \mathrm{E} \\ 3 & 29 & 15 & 3.5 & 4 \mathrm{~F}\end{array}$

\section{Other Possible Tools}

\section{End Scraper $(n=1)$ (Surface)}

This artifact is made on the distal end of a cortex flake that is slightly curved in longitudinal profile. The cortex is brown and the interior chert is a light gray. The specimen was made from a good quality chert gravel cobble. Length: $39 \mathrm{~mm}$; Width: 20 $\mathrm{mm}$; Thickness: $7 \mathrm{~mm}$.

\section{Perforators $(n=2)$}

One, Lot \#18 (see Figure 1Q), is a pointed chert sliver retouched unifacially into a point. It is $22 \mathrm{~mm}$ long, $10.5 \mathrm{~mm}$ wide, and $6 \mathrm{~mm}$ thick. The second specimen is from Lot 25 (not illustrated) and is a bi-pointed sliver of chert worked on both ends. It is 19 $\mathrm{mm}$ long, $11 \mathrm{~mm}$ wide, and $5 \mathrm{~mm}$ thick.

\section{Debitage $(\mathrm{n}=116)$}

The debitage sample is presented in Table 6. For distributional purposes, the sample is considered to be all from a single component; no intra-site distributional studies are attempted. 
Table 6. Debitage distribution at the Redwine site.

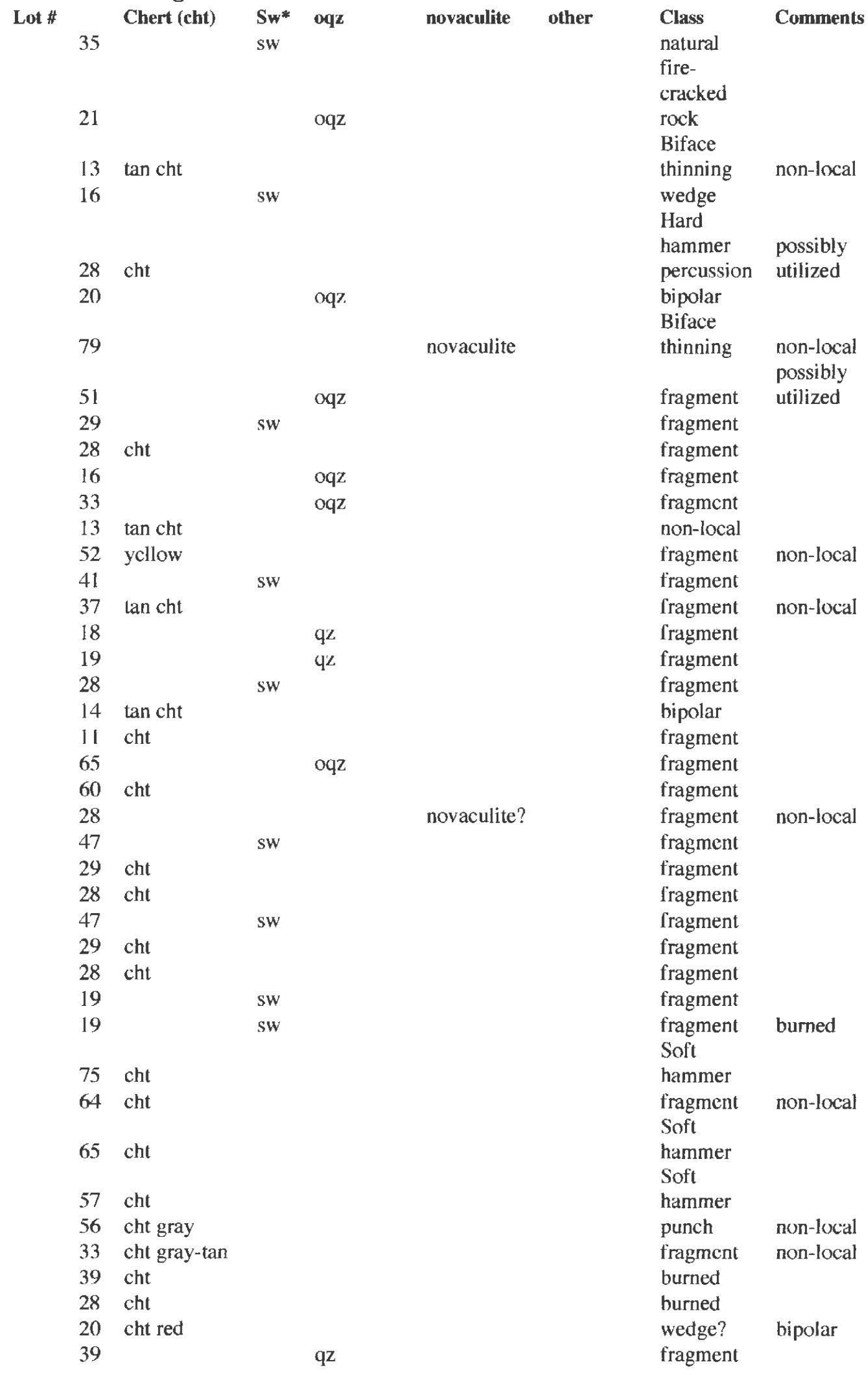




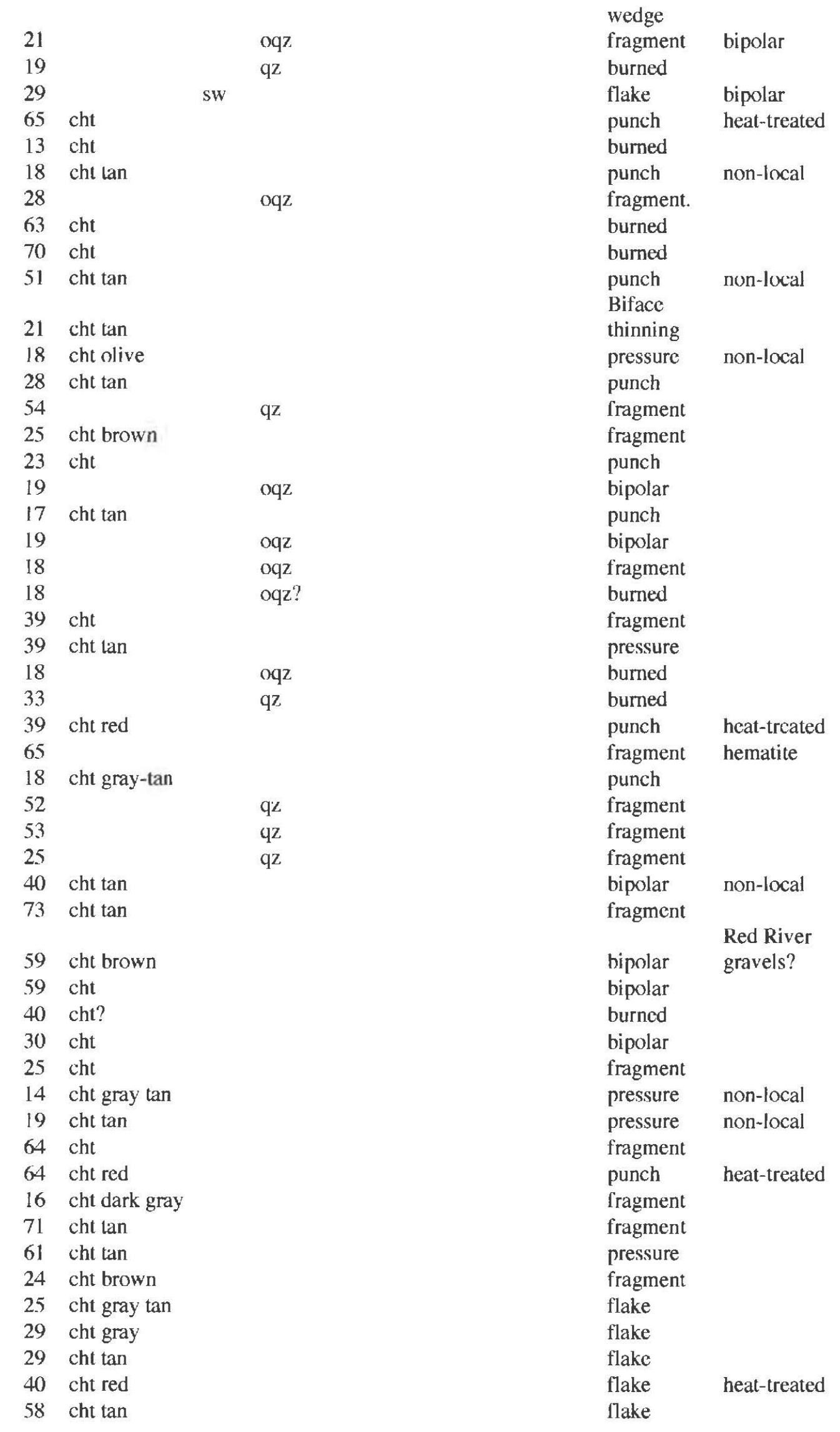




\begin{tabular}{|c|c|c|c|}
\hline 35 & cht gray & & fragment. \\
\hline 31 & cht gray & & fragment \\
\hline 13 & cht gray & & fragment \\
\hline 21 & cht $\tan$ & & fragment \\
\hline 30 & cht gray tan & & fragment \\
\hline 15 & & sw & fragment \\
\hline 47 & cht & & Cragment \\
\hline 12 & & sw & flake \\
\hline 18 & & $\mathrm{q} z$ & fragment \\
\hline 23 & & $\mathrm{q} z$ & fragment \\
\hline 18 & & $\mathrm{q} z$ & fragment \\
\hline 21 & cht & & fragment \\
\hline 21 & cht & & fragment \\
\hline 41 & & ૦بz & flakc \\
\hline 18 & cht & & burned \\
\hline 42 & & sw & flake \\
\hline 31 & cht tan & & fragment \\
\hline 75 & cht tan & & fragment \\
\hline 30 & cht & & burned \\
\hline 39 & cht dark gray & & flake \\
\hline 35 & cht gray & & fragment \\
\hline 43 & cht & & flake \\
\hline 65 & cht & & fragment \\
\hline 28 & cht & & fragment \\
\hline
\end{tabular}

$*_{\mathrm{sw}}=$ silicified wood; $\mathrm{qz}=$ quartzite; oqz=orthouuartzite; cht=chert

The sample consists of small to very small pieces of material, most being less that $10 \mathrm{~mm}$ in size. Chert accounts for $65.5 \%$ of the sample, while orthoquartzite and quartzite combined account for $\mathbf{2 2 . 4 \%}$. Orthoquartzite constitutes half of this group $(11.2 \%)$. Silicified wood constitutes $10.3 \%$, while novaculite is barely represented at $1.7 \%$.

In contrast, the material categories were notably different at the Leaning Rock site. There, both silicified wood (54 specimens, or $33.5 \%$ ) and chert (54 specimens, or $33.5 \%$ ) occurred in equal proportions while orthoquartzite ( 50 specimens or $31 \%$ ) was slightly less (Shafer 2007b). The differences between the two assemblages may be accounted for by a more prominent Woodland presence in the multi-component assemblage from the Leaning Rock site. Woodland assemblages in this part of East Texas have a high frequency of orthoquartzite and silicified wood (Shafer and Green 2007). The much higher frequency of chert at Redwine may signal Middle Caddo material preferences. Considering the interaction networks that likely occurred within the Caddo regional settlements, chert probably was a popular commodity of exchange.

The technology represented in the debitage sample is consistent with that which would be expected working with small resources. The frequency of any one reduction method is hard to quantify given the small size and fragmentary nature of the debitage sample. Therefore, only raw counts of those flakes whose reduction technology is identified are listed. Bipolar flakes and nuclei are present $(n=11)$, and the latter may be 
wedges for splitting wood. Bipolar technology to reduce small pebbles is a consistent technology in East Texas (Girard 1995; Shafer 1973:107-114) and its presence in the Redwine assemblage is not unexpected. Small lipped and curved flakes have attributes consistent with their removal using a punch or indirect percussion $(n=13)$. Pressure flakes $(n=5)$ are also present in the sample along with biface thinning flakes $(n=3)$. Hardhammer percussion was identified by one example but here again the paucity is attributed to the small size of the raw material.

\section{Ground Stone}

Seven items considered to be ground stone artifacts were submitted for analysis. These include a ground stone celt bit fragment, the possible poll end of a celt, a highly polished fragment of a ground stone artifact of unknown form, polishing stones, and a sandstone pebble. Three of these artifacts were listed as celt fragments by Walters and Haskins (1998:12 and Figure 7C).

\section{Celt fragments $(n=2)$}

One is a split portion retaining the bit end of a small celt of imported quartzitic sandstone with a dark olive tint, a common material in Caddo celt manufacture. Banks and Winters (1975:27) have described outcrops of this material in the Ouachita Mountains and identify it as either from the Stanley Shale or Jackfork Formation. The technology of manufacture was pecking and grinding, and peck marks, although partly smoothed, are quite visible over much of the exterior surface, excluding the bit. The specimen was broken by a massive impact. Interestingly, the fragment was recycled and both lateral edges of the fragment were used as saws as evidenced by edge smoothing and rounding. It was recovered from Lot \#9. Length: $74 \mathrm{~mm}$; Width: $42 \mathrm{~mm}$; Thickness: 14 $\mathrm{mm}$.

The second fragment is possibly the poll end of a celt manufactured from a reddish-brown quartzitic sandstone coarser than the first celt fragment. The fragment appears to have been broken by a massive impact at the poll end. Peck marks cover the surface and there is no evidence of smoothing. The question as to whether or not this is indeed a celt fragment comes with a slight curvature of the surface that is not consistent with a celt form. It is grouped here under celts, however, because of the raw material and technology. Lot \# 73. Length: $39 \mathrm{~mm}$; Width: $32 \mathrm{~mm}$; thickness: $16 \mathrm{~mm}$.

There is no evidence that celts were manufactured from blanks brought to the site. The general pattern throughout the Caddoan archaeological area in Texas is that celts of exotic material were imported into the area in finished form (see Banks and Winters 1975:35; Shafer 1973:299-309, 2007b). Furthermore, recycling of celt fragments would be expected in an area of impoverished lithic resources (see discussion below). 


\section{Polished stone fragment $(n=1)$}

This artifact is from a thermally broken highly polished stone artifact of a very fine grained reddish-brown sandstone. The stone is much finer than the celts described above, and may indeed be from a celt, although the shape and fine finish does not rule out some other type of polished stone artifact. The cross-section is circular. The polish is so thorough that all peck marks, if shaped by pecking, are obliterated. Lot \#58. Length: 32 mm; Width: $26 \mathrm{~mm}$; Thickness: $13 \mathrm{~mm}$.

This fragment could be from the shaft of a spatulate celt (see Shafer 1973: Figure $240, P)$, or from an earlier style Caddo celt form in which peck marks are obliterated (Shafer 1973:309). The rounded contour of the fragment is not consistent with what I would expect with conventional celts, however. The even circular shape is more consistent with that of the shaft of a spatulate celt. Spatulate celts are rare in the Caddoan archaeological area, and the best known examples are mostly from major Early Caddo mound centers such as the George C. Davis, Gahagan, and Spiro sites. Heirloom examples or recycled fragments would not be out of character in Middle Caddo lithic assemblages in East Texas.

\section{Polishing stones $(n=3)$}

Two pebbles of chert and another of sandstone show evidence of use as polishing stones. Two chert pebbles are likely ceramic pot-polishing stones. The sandstone pebble shows possible faceting from use as an abrader or coarse smoothing stone. Chert polishing stones: Lot \#39. Length: $40 \mathrm{~mm}$; Width: $31 \mathrm{~mm}$, Thickness: $22 \mathrm{~mm}$; Lot \#57. Length: $29 \mathrm{~mm}$; Width: $24 \mathrm{~mm}$; Thickness: $16 \mathrm{~mm}$. Sandstone polishing stone: Lot \#56. Length: $44 \mathrm{~mm}$; Width: $30 \mathrm{~mm}$ : Thickness: $28 \mathrm{~mm}$.

Pot polishing stones were used during the process of burnishing while the ceramic body is leather hard (see Shafer 2007b for further discussion). The presence of polishing stones at Redwine is consistent with the findings at the Leaning Rock site asscmblage, and like at the Leaning Rock site, they provide circumstantial evidence that potters were at work at this site. The ceramic assemblage at Redwine contains both fine wares and utility pottery (Walters and Haskins 1998). While the replacement rates for ceramics have not been quantified, there is certainly ample evidence from the sherd assemblages that ceramics were used and broken. Replacement of broken vessels would certainly be expected and the artifacts used in the production of new vessels, namely pot polishing stones, would also be expected.

\section{Sandstone Pebble $(\mathrm{n}=1)$}

This flat and oval sandstone pebble may have been an artifact, but if so, its use is not indicated by any surface attribute. It is considered a manuport with no indication of function. Lot \#20. Length: $39 \mathrm{~mm}$; Width: $33 \mathrm{~mm}$; Thickness: $12 \mathrm{~mm}$. 


\section{Other Lithic Artifacts $(\mathrm{n}=3)$}

Walters and Haskins (1998:12, 14 and Figure 7D-E) list two sandstone abraders and a hammerstone in the Redwine lithic assemblage.

\section{DISCUSSION}

While the typological system for projectile points in East Texas is alive and well (Suhm, Krieger, and Jelks 1954; Suhm and Jelks 1962; Turner and Hester 1999), it is not without problems. Mortuary clusters of arrow points recovered from the Redwine site illustrate some of these problems. Most mortuary arrow points are pristine and are often made of non-local materials (Cluster 1 from Burial 3 may be an exception to this pattern), whereas arrow points recovered from midden and village contexts are of both local and non-local materials and many represent the nubbin end of the use (as opposed to production) side of the linear reduction sequence (e.g., Shafer 1983). In other words, it is somewhat like classifying oranges and apples and trying to use the same typology to classify the domestic and mortuary samples. The differences between domestic arrow points and mortuary arrow points are not unlike that observed with Caddo ceramics (Perttula 1998a:237).

But how points got into the mortuary assemblage in the first place could be the consequence of a complex of social behaviors. For example, are the mortuary items the personal possessions of the deceased? Griffith (1954:94-96) describes the burial of a high ranking Hasinai Caddo male in which personal possessions, including his "hatchet," were placed in his grave and a bow and arrow was placed on top of the coffin. Single arrows may have been placed in graves of both sexes for purely symbolic reasons. These behaviors may explain clusters of arrow points, single arrow points, and celts in male graves if these mortuary practices were more culturally widespread among the Caddo. Griffith's description may also explain why some mortuary items are encountered above the burial itself if they had been placed on top of the coffin. Are mortuary items a composite of artifacts offered by kinsmen, clansmen, or others to outfit the deceased on their journey? Griffith (1954:96) again mentions men providing gifts of arrows and other items to the wife or mother of the deceased. In the Hasinai Caddo example, these items were cremated, but variability in such behavior may explain the inclusion of stylistically variable arrow point clusters in a single grave. If the latter, a quiver could be made up of arrows provided by numerous individuals or by a single individual. And are the items coming from a local pool of knappers, or are they being introduced from outside the immediate area? From Griffith's accounts, it cannot assumed that the items interred with an individual belong to that individual.

Grave inclusions may consist of a very consistent technological and typological group, or display a great deal of variability, with regards to both style and technology, as for example with Burial 3, Clusters 1 and 2 arrow points from the Redwine site described here. Although later in time than the Redwine site, Burial 23 at the Tuck Carpenter site (Turner 1978) had three separate types (Maud, Perdiz, and Bassett) included in four separate clusters. Burials 19 and 28 at the Alex Justiss site are other examples. Burial 
19 had three side notched points (one with an upper blade portion that was deeply serrated) classified as a "Washita" (Rogers et al. 2003: Figure 39) although none conform to the technological style of the Washita arrow point shown in Figure 40v of Rogers et al. (2003). The Burial 19 "Washita" points are more like the side-notched points described by Bell (1981: Figure 41) from the Alex Justiss site. Bell does not classify the points as to type, but compares them to either the Harrell (which they are not) or Reed (which they may be) points. Burial 28 at the Alex Justiss site had 19 Talco points, one "Perdiz" (Perdiz-Bassett?), and an untyped arrow point.

I do think that at least four separate flint knappers were responsible for the arrow points that were interred with Burial 1, Cluster 1 at Redwine, while a single flint knapper was responsible for Burial 1, Cluster 2. A separate knapper was probably responsible for the Burial 3, Cluster 2 points. More technological and stylistic variability was apparent in the arrow points from Burial 1, Cluster I and Burial 3, Cluster 1. While a study of the mortuary arrow point clusters from Redwine does not answer any of the perceived questions regarding variability between mortuary arrow points and those recovered from midden and village contexts, or the variability among mortuary clusters and even points in a single cluster, the study does shine some light on interpretive problems regarding typology and explaining the morphological, stylistic, and technological variability of the recovered archaeological samples.

\section{COMPARISONS}

Detailed studies of mortuary-associated lithics from Caddo graves are often lacking in the East Texas archaeological literature although there are notable exceptions (e.g., Perttula 1998b; Rogers et al. 2003; Shafer 1973; Turner 1978). Mortuary arrow points do not always conform to the predominant styles found in household refuse. Burial 1, Cluster 2 from Redwine described above is a good example. Other examples that do not fall into established types are the group of side-notched arrow points in the Nicholas collection from the Alex Justiss site (Bell 1981: Figure 41), and the square-stem points from Burial 11 at the Mockingbird site (Perttula 1998b). While broad comparisons of Middle and Late Caddo mortuary arrow points are beyond the scope of this paper, a thorough study of style, technology, raw material, artifact association (e.g., pipes and celts), and gender association would undoubtedly be fruitful. Perttula's (1998b), Rogers et al. (2003), and Turner's (1978) studies at Mockingbird, Alex Justiss, and Tuck Carpenter sites, respectively, provide a good beginning, at least for the Titus phase.

The correlation of raw material with point styles may show some significant patterning in time and space. For example, Turner (1978) noted triangular arrow points (Maud and Talco) and Bassett points were made of heat-treated orthoquartzite while Perdiz points were not made of orthoquartzite at the Late Caddo Carpenter site. Perdiz, Bassett, and Maud were all found in one grave (Grave 23). This Titus phase pattern held true at the Alex Justiss (Rogers et al. 2003) and Mockingbird sites (Perttula 1998b:315). A geographic study of the distribution of heat treated orthoquartzite (Ogallala quartzite) arrow points (Maud, Bassett, and Talco) might be fruitful. Seemingly at this time, the 
Late Caddo cluster with which the Carpenter site was affiliated had less contact with Central Texas compared to the earlier Sabine and Neches River clusters of Caddo sites. In other words, with broader studies of raw material and technological styles one might be able to further define interacting groups and how these interactions changed through time using material other than ceramics.

Among the issues addressed in this paper regarding technology is the variability of material, form, and manufacturing technology to determine if a mortuary cluster of arrow points was produced by a single flint knapper. The material issues involve raw material. The areas of East Texas south of the Red River are generally impoverished when it comes to lithic raw material suitable for chipped stone tools. Two methods of securing good tools were to either import the raw material or obtain finished products from elsewhere where good raw material existed.

A contextual study of mortuary goods should emphasize the location and orientation of the artifacts within the grave, as this would provide information on the placement of composite artifacts such as arrows, celts, and pipes. It is unfortunate that such information is lacking in the Redwine assemblage other than simple presence or absence. The inclusion of arrow points, probably as quivers, and pipes would certainly suggest an assemblage associated with males (Turner 1978). We can assume that along with the arrow quivers, bows were included as well based on perishable information from the Mounds Plantation site (Webb and McKinney 1975). Mortuary assemblages that are linked to females have yet to be defined in Middle Caddo assemblages, but one might assume that graves in which male-linked artifacts are absent were most likely females, Burials 2 and 4, for example, at the Redwine site.

One objective of this study was to analyze the chipped stone collection from the Redwine site and compare it to the nearby Leaning Rock site. It is preferable in archeological studies to integrate all classes of material culture in analysis and interpretation to see what sets of material co-occur both functionally and stylistically. The ground stone artifacts from the Leaning Rock site (Shafer 2007b) provided two important pieces of information on celt technology and the importation of celt bits to the site, and the polished stone artifacts provided sound evidence of ceramic manufacture. Similarly, celts imported as finished tools also occurred at Redwine (Walters and Haskins 1998). The mortuary and village ceramic assemblages from the Redwine site provided an independent confirmation of the chronological and regional placement for the material culture assemblage. Certain ceramics from Redwine compare with other sites, notably the George C. Davis site and the Washington Square Mound site. The George C. Davis site yielded arrow point styles, and Crockett Curvilinear Incised and Pennington Punctated Incised vessels, that also occur with the Redwine burials (Burial 3 and 1, respectively). Vessels of Nacogdoches Engraved were recovered from the same burials; the Washington Square Mound site is the type site for Nacogdoches Engraved (Perttula in Walters and Haskins 1998). Washington Square Mound ceramic motifs (Nacogdoches Engraved and Washington Square Paneled) have also been identified at the Leaning Rock site (Timothy K. Perttula, 2007 personal communication), suggesting that the two sites were essentially contemporaneous with regards to their ceramic assemblages. Also, 
engraved pottery with similar body motifs to Nacogdoches Engraved occurs at the George C. Davis site but are defined as Hickory Fine Engraved (Newell and Krieger 1949:Figure 33F) or as "Miscellaneous engraved" Newell and Krieger 1949:Figure 34A, C, F). At first glance there appears to be a continuity and transition of style in certain ceramics and arrow points between the George C. Davis site and Washington Square. Redwine may lie within the time of this transition.

Comparing the debitage from the Leaning Rock and Redwine sites does reveal some possibly significant differences. For example, chert and silicified wood occurred at the Leaning Rock site in equal proportions (33.5\%) while orthoquartzite was slightly less in representation $(31 \%)$. Chert is the most common raw material at Redwine $(65.5 \%)$, while orthoquartzite $(27.4 \%)$, silicified wood $(10.3 \%)$, and novaculite (2\%) are less well represented. These differences are probably reflected in the fact that Late Archaic and Woodland components are better represented in the Leaning Rock collection. This likelihood is bolstered by the fact that no Late Woodland or Early Caddo lithics were identified in the Redwine collection. The dominance of chert is attributed to the Middle Caddo occupation and probably reflects their wider interaction with groups occupying the chert-rich prairies to the west.

The Redwine debitage sample consists of very small flakes, less that $2 \mathrm{~cm}$ in size for the most part, that often do not carry attributes that would indicate the methods of detachment. I did note the flake types as I sorted the sample. These are only 36 of the 116 pieces of debitage that carry attributes suggestive of reduction methods. Of these, 11 are bipolar, 17 are probably punch flakes (one is a biface thinning flake), and seven are pressure flakes. At the Leaning Rock site, bipolar, pressure, and punch were the most common reduction methods recognized in the sample although I did not quantify their representation (Shafer 2007b).

One observation regarding debitage deserves to be mentioned, and that is the fact that virtually all usable material gets reduced to sizes that are too small for further use. Even tiny perforators are made from small pieces of retrieved debitage, and fragments of imported items such as celts were recycled and used as expedient tools. This widespread pattern throughout East Texas points to the fact that East Texas was a consumer area for high quality raw materials such as chert and hard stone for celts, and not a production area. This is a predictable pattern where people living in a geographic area without high grade chert or some other cryptocrystalline stone such as novaculite or obsidian obtain either raw materials or finished products from adjacent regions rich in such resources.

People living in lithic-impoverished regions make the most of what they have available, and the Caddo certainly did that, but quality raw material and finished products made of that material were readily obtained. Once obtained, the quality material was reduced, retouched, and recycled to the point that it was not longer usable. The best evidence for this pattern that I have seen was with the ancient Maya in northern Belize. The site of Colha was a major lithic production site situated on huge deposits of high quality chert (Shafer and Hester 1983). Many lithic workshops were mapped and tested to define the types of formal tools being manufactured at Colha. Literally millions of 
tools were produced in the workshops and these were exchanged into areas with poor lithic resources as finished products. Once in the hands of the consumers, however, the tools were used, broken, recycled, and often recycled again as tools or small cores before being discarded (Shafer 1983; Dockall and Shafer 1993). The debitage also clearly reflected this linear process. The producer-consumer pattern is well documented in the Maya Lowlands with regards to the distribution of chert artifacts, for example (Dockall and Shafer 1993; McAnany 1986; Shafer 1983), and is now quite well documented for the Caddo and Central Texas areas (Shafer 1973:343). When the producer-consumer model is applied to Central and East Texas, Central Texas is the producer area and East Texas is the consumer area for high quality Edwards chert and finished celts of stone from the Ouachita Mountains. The Caddo may have been obtaining chert directly by actually coming into Central Texas periodically or on hunting expeditions (see Shafer $|2007 \mathrm{a}|$ for a perspective on this point), or they may have obtained it indirectly through exchange. Celt bits were likely items of exchange.

\section{SUMMARY AND CONCLUSIONS}

The relatively small lithic artifact sample of 158 specimens recovered from the Redwine site has revealed significant information on the uses of local and non-local raw materials, technological patterns, styles, and technology in mortuary arrow point assemblages. While no resounding observations came from the analysis, it is important to build a reference base for more definitive comparisons of lithic artifacts across the Caddo world.

The sample consists of three dart points, 36 arrow points, an end scraper, and two tiny perforators. The debitage sample consists of small flakes and chips of chert, silicified wood, orthoquartzite, and novaculite. Evidence of hard-hammer, punch, pressure, and bipolar flaking was present in the debitage. Punch (indirect percussion) and pressure flakes were the most readily identifiable in the sample that consisted of mostly very small pieces of debitage.

Although the sample is small and lacks formal tools other than arrow points, it is significant in several respects. It provides an important comparative data base for Middle Caddo arrow point styles, both from midden and mortuary contexts. The technological differences between the mortuary and midden arrow point samples suggest somewhat different attitudes with regard to arrow points as used in everyday life and arrow points placed in graves. Mortuary arrow points often do not exhibit the type modes expected and may carry significant symbolic roles not often considered in archeological studies. Also, the chipped stone sample does reflect a Middle Caddo chronological placement based on the stylistic bridges between the Stage V burials at the George C. Davis site and the historic Caddo period arrow point assemblage at the Deshazo site. 


\section{ACKNOWLEDGMENTS}

1 want to thank Mark Walters for providing the opportunity to study the Redwine and Leaning Rock lithics, and for his patience in waiting for the results of the analyses. Also, Tim Perttula has been most helpful in providing comments and references to "gray" literature on archaeological excavations in East Texas.

\section{REFERENCES CITED}

Banks, L. D.

1990 From Mountain Peaks to Alligator Stomachs: A Review of Lithic Sources in the Trans-Mississippi South, the Southern Plains, and Adjacent Southwest. Memoir No. 4. Oklahoma Anthropological Society, Norman.

Banks, L. D. and J. Winters

1975 The Bentsen-Clark Site, Red River County, Texas: A Preliminary Report. Special Publication No. 2. Texas Archeological Society, San Antonio.

Bell, M.

1981 The Alex Justiss Site: A Caddoan Cemetery in Titus County, Texas. Publications in Archaeology Report No. 21. Texas Department of Transportation, Austin.

Brewington, R. L., J. E. Dockall, and H. J. Shafer

1995 Archaeology of 41MX5: A Late Prehistoric Caddoan Hamlet in Morris County, Texas. Reports of Investigations No. 1. Center for Environmental Archaeology, Texas A\&M University, College Station.

Corbin, J. E. and J. P. Hart

1998 The Washington Square Mound Site: a Middle Caddo Mound complex in South Central East Texas. Bulletin of the Texas Archeological Society 69:47-78.

Dockall, J. E. and H. J. Shafer

1993 Testing the Producer-Consumer Model for Santa Rita Corozal, Belize. Latin American Antiquity 4:158-179.

Gadus, E. F., J. K. McWilliams, and R. C. Fields

2002 Data Recover Excavations at the McGuire's Garden Site (41FT425), Jewett Mine, Freestone County, Texas. Reports of Investigations No. 134. Prewitt and Associates, Inc., Austin.

Girard, J. S.

1995 The Chipped Stone Collection: Technological, Functional, and Typological Analysis. In: The Deshazo Site, Nacogdoches County, Texas, Vol. 2: Artifacts of Native Manufacture, edited by D. A. Story, pp. 33-156. Studies in Archeology 21. Texas Archeological Research Laboratory, The University of Texas at Austin. 
Griffith, W. J.

1954 The Hasinai Indians of East Texas as Seen by Europeans, 1686-1772.

Philological and Documentary Studies, Vol. II (3). Middle American Research Institute, Tulane University, New Orleans.

Lechtman, $\mathrm{H}$.

1977 Style in Technology - Some Thoughts. In Material Culture: Styles, Organization, and Dynamics of Technology, edited by H. Lechtman and R. Merrill, Pp. 320. West Publishing Co., St. Paul.

McAnany, P. A.

1986 Lithic Technology and Exchange among Wetland Farmers of the Eastern Maya Lowlands. PhD. dissertation, Department of Anthropology University of New Mexico, Albuquerque.

McGregor, Daniel E.

1993 Pisgah Ridge Chert Distributions: Evidence for Changing Territorial Size in North Central Texas. Bulletin of the Texas Archeological Society 64:247-267.

Newell, H. P. and A. D. Krieger

1949 The George C. Davis Site, Cherokee County, Texas. Memoirs No. 5. Society for American Archaeology, Menasha, Wisconsin.

Perttula, T. K.

1997 Archaeology of the Middle Caddoan Period in the Middle Red River Valley of Northeast Texas. Journal of Northeast Texas Archaeology 10:47-51.

1998a The Mockingbird Site Vessel Assemblage. In Analysis of the Titus Phase Mortuary Assemblage at the Mockingbird Site: "Kahbakayammaahin" (41T7550), by T. K. Perttula, M. Tate, H. Neff, J. W. Cogswell, M. D. Glascock, E. Skokan, S. Mulholland, R. Rogers, and B. Nelson, pp. 215-253. Document No. 970849. Espey, Huston \& Associates, Inc., Austin.

1998b Stone Artifacts. In Analysis of the Titus Phase Mortuary Assemblage at the Mockingbird Site: "Kahbakayammaahin" (41TT550), by T. K. Perttula, M. Tate, H. Neff, J. W. Cogswell, M. D. Glascock, E. Skokan, S. Mulholland, R. Rogers, and B. Nelson, pp. 310-327. Document No. 970849. Espey, Huston \& Associates, Inc., Austin.

Rogers, R. M. B. Cliff, T. K. Perttula, G. Rutenberg, S. Victor, P. Dering, and M. Malainey

2003 Excavations at the Alex Justiss Site, 41TT13, Titus County, Texas. Document No. 030089, PBS\&J, and Archeological Studies Program Report No. 36, Texas Department of Transportation, Austin. 
Rogers, R. and T. K. Perttula

2004 The Oak Hill Village Site (41RK214), Rusk County, Texas. PBS\&J, Austin.

Shafer, H. J.

1973 Lithic Technology at the George C. Davis Site, Cherokee County, Texas. Ph.D. dissertation, Department of Anthropology, The University of Texas at Austin.

1983 The Lithic Artifacts of the Pulltrouser Swamp area: Settlements and Fields. In Pulltrouser Swamp: Ancient Maya Habitat, Agriculture, and Settlement in Northern Belize, edited by B. L. Turner II and P. D. Harrison, pp. 212-245. University of Texas Press, Austin.

2007a People of the Prairie: A Possible Connection to the Davis Site Caddo. Research module published on-line by the Council of Texas Archeologists, Prairiecaddomodule.pdf.

2007b Leaning Rock Site (41SM325) Lithics. Caddo Archeology Journal 16:57-70.

Shafer, H. J. and L. Green

2007 Tuinier Borrow Pit Biface Cache, Hopkins County, Texas. Caddo Archeology Journal 17 , in press.

Shafer, H. J. and T. R. Hester

1983 Ancient Maya Lithic Workshops at Colha, Belize. American Antiquity 48:519543.

Story, D. A.

1997 1968-70 Archeological investigations at the George C. Davis Site, Cherokee County, Texas. Bulletin of the Texas Archeological Society Vol. 68: 1-103.

Suhm, Dee Ann and Edward B. Jelks (editors)

1962 Handbook of Texas Archeology: Type Descriptions. Texas Archeological Society Special Publications No. 1, Texas Memorial Museum Bulletin No. 4. Austin.

Suhm, D. A., A. D. Krieger, and E. B. Jelks

1954 An Introductory Handbook of Texas Archaeology. Bulletin of the Texas Archeological Society 25:1-562.

Turner, R. L.

1978 The Tuck Carpenter Site and Its Relations t Other Sites within the Tutus Focus. Bulletin of the Texas Archeological Society 49:1-I10.

Turner E. S. and T. R. Hester

1999 A Field Guide to the Stone Artifacts of Texas Indians. Gulf Publishing Company, Houston. 
Walters, M. and P. Haskins, with contributions by D. H. Jurney, S. E. Goldborer, and T. K. Perttula

1998 Archaeological Investigations at the Redwine Site (41SM193), Smith County, Texas. Journal of Northeast Texas Archaeology 11:1-38.

Webb, C. H. and R. R. McKinney

1975 Mounds Plantation (16CD12), Caddo Parish, Louisiana. Louisiana Archaeology 2:39-127. 